\title{
Popular medicinal uses of Calea uniflora Less. (Asteraceae) and its contribution to the study of Brazilian medicinal plants
}

\author{
LUAN S. RAMOS ${ }^{1}$, PAULA S. CARDOSO ${ }^{1}$, MICHELE D. FREITAS ${ }^{1}$, RENATO \\ PAGHAN ${ }^{1}$, MARÍLIA S. BORGES ${ }^{1}$, VANILDE CITADINI-ZANETTE ${ }^{2}$, JAMES \\ W. BARLOW ${ }^{3}$, PATRÍCIA A. AMARAL ${ }^{1}$ and SILVIA DALBÓ ${ }^{1}$ \\ ${ }^{1}$ Laboratório de Plantas Medicinais (LaPlaM/ PPGCA), Universidade do Extremo Sul Catarinense/ \\ UNESC, Avenida Universitária, 1105, Bairro Universitário, 88806-000 Criciúma, SC, Brazil \\ ${ }^{2}$ Herbário Pe. Raulino Reitz, Universidade do Extremo Sul Catarinense/UNESC, Avenida \\ Universitária, 1105, Bairro Universitário, 88806-000 Criciúma, SC, Brazil \\ ${ }^{3}$ Department of Pharmaceutical and Medicinal Chemistry, Royal College of Surgeons in \\ Ireland, 123 St. Stephens Green, 2, 00000-000 Dublin, Leinster, Ireland
}

Manuscript received on March 6, 2016; accepted for publication on July 12, 2016

\begin{abstract}
Calea uniflora Less. is widely used in southern Santa Catarina (Brazil), but there are no scientific studies which support its use. Then, this study was proposed to determine of the percentage use of C. uniflora in a city of southern Brazil and documentation of the knowledge that the population has about this species. The survey was conducted with semi-structured interviews using a questionnaire applied to 372 participants. In analyzing the results, it was observed that of the $94.1 \%$ who recognized C. uniflora, $74.3 \%$ utilize it as a medicinal plant and $65.4 \%$ of such knowledge originates in childhood, mainly through the family $(84.6 \%)$. $93 \%$ reported using inflorescences macerated in alcohol or rum; this extract is generally used topically for wound healing and muscle pain. Furthermore, some reported using small quantities of this extract orally to treat cold and flu. Regarding effectiveness and safety, 97\% stated an improvement in symptoms with the use of the plant, while $98.5 \%$ stated that it has no toxicity. In light of these results, future phytochemical, pharmacological and toxicological analyses should be designed in order to ensure rational and safe use of this species.
\end{abstract}

Key words: Brazil, Calea uniflora, ethnobotanical studies, semi-structured interviews, traditional medicine.

\section{INTRODUCTION}

Saslis-Lagoudakis et al. (2014) claim that an important point for change in history is the ability of humans to learn from others and transmit this knowledge to those who live around them, thus

Correspondence to: Silvia DalBó

E-mail:sildb@unesc.net ensuring the transmission and conservation of information. In the context of medicinal plant use this is no different, as traditional knowledge is usually transmitted orally and associated with families, communities or ethnic groups (Hamilton 2004, Abbet et al. 2014). However, lifestyle change associated with lack of ethnobotanical surveys and recording of information, may result in the loss of 
traditional knowledge for future generations (Dovie et al. 2008, Simbo 2010, Maroyi 2011, Wambugu et al. 2011).

Such observations under in the importance of ethnobotany, as studies in this discipline are intended to investigate for what purposes plants are used, while recording and ensuring the preservation of information (Sargin et al. 2013, Liu et al. 2014). In addition, these studies may also support the evolution of phytochemical and pharmacological analyses, since plant extracts present a promising resource for the discovery of substances with pharmacological activity (Nascimento and Oliveira 2004, Heinrich et al. 2014).

Among the diverse plant kingdom is the family Asteraceae, with approximately 1.535 genera and 23.000 species distributed in cosmopolitan fashion, but occurring predominantly in tropical and subtropical regions (Maia et al. 2011, Nascimento and Oliveira 2004).Within this family is found the Calea genus of plants, comprising around 110 species, including the medicinal species Calea uniflora Less., a perennial herb with yellow inflorescences, popularly known as arnica-da-praia (Nascimento et al. 2002, 2004). As described by (Mondin et al. 2015), C. uniflora is heliophytic and develops in a subtropical climate. This species is native to Paraguay, Argentina, Uruguay and Brazil. In Brazil, is found in the center-south of the country (Mato Grosso do Sul, Minas Gerais, São Paulo, Paraná, Santa Catarina and Rio Grande do Sul (Mondin et al. 2015). In particular, the plant is well distributed in the south of Santa Catarina in the coastal area in well-drained soil regions, appearing spontaneously in Balneário Rincão city, where usually is collected by the local population and neighboring municipalities.

Some scientific studies have been developed to determine the phytochemical and pharmacological activities. Phytochemical studies reported to date with $C$. uniflora have identified a range of secondary metabolites including rel-2-methyl-2,3,4-trihydroxybutanoic acid-1,4-lactone, 5-deoxyflavone glycoside, 3',4',7-trihydroxyflavone-7-O- $\beta$-glucopyranoside, 2 ', 4-dihydroxy-3-methoxychalcone-4' - $O$ $\beta$-glucopyranoside and quercetin-3-O- $\beta$ galactopyranoside (Nascimento and Oliveira 2004). Also, Lima et al. (2016) describes the presence of nine phenolic compounds in leaves of $C$. uniflora, identified as noreugenin, ethyl caffeate, a mixture of butein + orobol, $\alpha$-hydroxybutein, caffeic acid, butein 4〉-O-glucopyranosyl, quercetin 3-O-glucopyranosyl and 3,5-di-Ocaffeoylquinic acid. The same authors demonstrate the trypanocidal effect of ethyl caffeate, a mixture of butein + orobol obtained by this plant. Furthermore, Nascimento et al. (2007) demonstrated that chromanones, uniflorol-A and uniflorol-B, isolated from C. uniflora inhibited the growth of promastigote forms of Leishmania major. In another study, both a dichloromethane extract of the roots and two isolated compounds derived from $p$-hydroxyacetophenone also showed trypanocidal properties. All compounds tested were also active against dermatophyte fungi (Trichophyton rubrum and T. mentagrophytes), but only three against Candida albicans and C. glabrata (Nascimento et al. 2004). The dichloromethane extracts of both xylopodia and aerial parts showed in vitro trypanocidal activity against trypomastigotes of Trypanosoma cruzi (Nascimento et al. 2002).

According to local knowledge transmitted orally, this plant is widely used as a medicinal plant in southern Brazil, but to date scientific studies to support this use are lacking, an important factor in motivation of this research. Fundamentally, this research project aimed to determine the percentage use of C. uniflora in a city of Santa Catarina state in southern Brazil and establish the extent of knowledge that the population has about this species. Based on this information, we glimpse subsidize studies on phytochemistry and the pharmacology of this plant. 


\section{MATERIALS AND METHODS}

\section{STUDY AREA}

This research was conducted in the city of Balneário Rincão, which is located in the state of Santa Catarina, southern Brazil, between geographic coordinates $28^{\circ} 49>53.0 » \mathrm{~S}$ and $49^{\circ} 14>06.7 » \mathrm{~W}$ (Fig. 1). With $13 \mathrm{~km}$ of coastline, it has two fishing platforms and six freshwater ponds, being located between the municipalities of Araranguá (South), Jaguaruna (north) and Içara (west), and the Atlantic Ocean (east). As a coastal city with a subtropical climate, it has in most of the year a much smaller population when compared to the summer months, which it reaches 150.000 inhabitants (Balneário Rincão 2014, Santa Catarina 2014). We chose this area of study due to its favorable characteristics for the development of $C$. uniflora, which can be found naturally in the region.

\section{STUDY POPULATION AND SAMPLE CALCULATION}

The sample was composed of men and women housed in Balneário Rincão, aged over 18 years, selected at random by knocking on doors. According to 2012 estimates, the population of this city was about 11.136 inhabitants (IBGE 2012). Thus, in calculation of the required sample size the following formula was applied (Jesus et al. 2009,
Silva et al. 2010): $\mathrm{n}=\mathrm{N} p(1-p) /(\mathrm{N}-1)(d / z)^{2}$ $+p(1-p)$; where $\mathrm{n}$ is the sample size, $z(1.96)$ corresponds to the $95 \%$ confidence coefficient, $d$ (0.05) sampling error, $p(0.5)$ a ratio to be estimated and $\mathrm{N}$ (11.136) the total population, reaching a representative sample (n) of 372 people.

\section{DATA COLLECTION}

For obtaining data, semi-structured interviews were conducted (Albuquerque et al. 2010), by applying an adapted form (Supplementary Material) of Silva et al. (2010), Allabi et al. (2010) and Rossato et al. (2012) between December 2013 and March 2014. We conducted a pilot survey to test the interviews. This form was composed of questions related to socio-demographic characteristics of participants (gender, age, education, etc.), and also the plant $C$. uniflora (part used, time and place of collection, method of preparation, administration, etc.).

An exemplar of $C$. uniflora was collected at Vereador Custódio Borges, Bairro Pedreira, city of Balneário Rincão, identified botanically by Dr. Vanilde Citadini-Zanette and Dr. Mara Rejane Ritter, and a herbarium sample deposited in the Herbarium of Pe. Raulino Reitz at the Universidade do Extremo Sul Catarinense (UNESC) as CRI 10.304.

The holding of interviews began after the participants gave informed consent, pursuant to

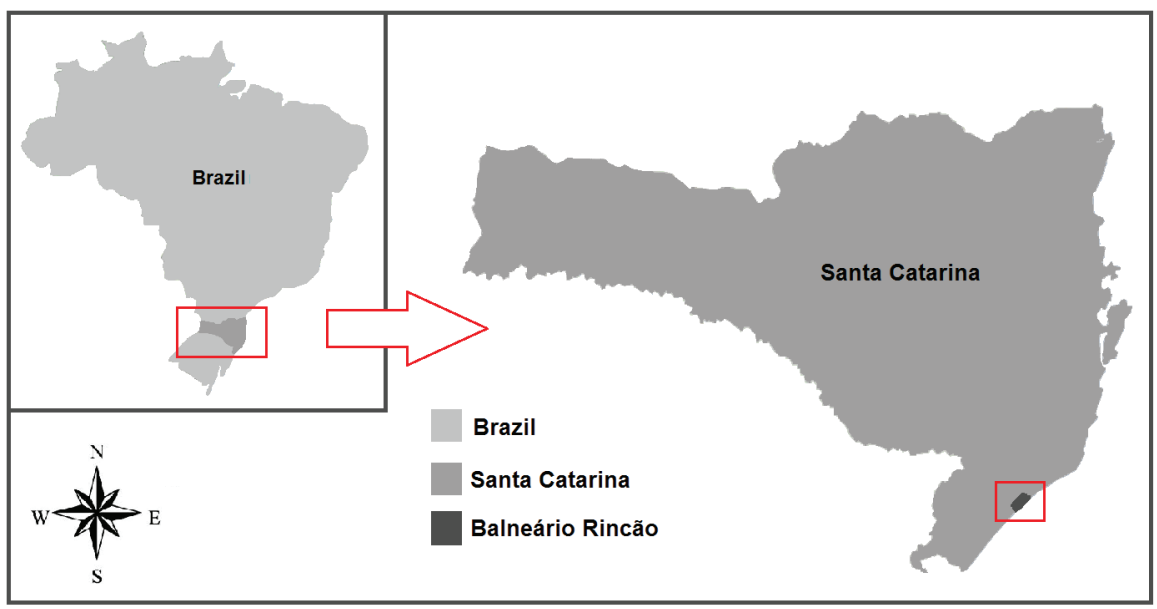

Figure 1 - Location of the city of Balneário Rincão. Font: Adapted Google Maps. 
Resolution No. 466 of December 12, 2012 of the National Council of Health (Brasil 2012). The implementation of this work was approved by the Research Ethics Committee of the Universidade do Extremo Sul Catarinense, registered under the No. 278.216

Initially, socio-demographic information on the participants was collected, and then the participants were asked whether they know arnica, and them an exemplar of plant was shown to each participant in order to confirm their recognition of the species, mentioning its popular name (arnica-da-praia) in situations where there was difficulty in recognition. All completed and signed interviews were collated, including those in which the participants reported not knowing or not using the plant.

\section{RESULTS}

Of the sample of 372 participants, the age profiles panned from 18 to over 70 years, with $37.1 \%$ between 30 and 50 years and $46.5 \%$ over 50 years. It was observed that women represented $74.2 \%$ of interviewees. The majority of $C$. uniflora users reported a monthly household income of no more than two minimum wages. Regarding time spent in formal education, it was observed that approximately $73 \%$ of C. uniflora users had completed primary education. However, over $20 \%$ also reported completion of high school or third level education (Table I).

On data relating to the study species, $50 \%$ of respondents recognized $C$. uniflora directly by the image, $44.1 \%$ by its popular name and only $5.9 \%$ reported not knowing it. Of the $94.1 \%$ ( $=$ $350)$ familiar with it, $74.3 \%(n=260)$ use it as a medicinal plant. Of those who use it, $65.4 \%$ said they knew it or used it since childhood, with an additional $13.8 \%$ reporting knowledge acquired in adulthood but retained for 20 years or longer. When asked about the origin of their knowledge, $84.6 \%$ said they learned of the plant through their family, $12.3 \%$ through friends or neighbours, and 3.1\% from other sources.

Considering the sourcing of the plant for consumption, $81.5 \%$ reported its collection in the region of Balneário Rincão in fields or in the bush, and while $56.5 \%$ said that the ideal harvesting period was from December to March, 25.8\% could not identify the optimal harvesting time.

In relation to its popular name, 97\% knew C. uniflora only as arnica-da-praia, while the remaining 3\% mentioned other names as arnica-docampo and arnica-do-mato, which may be related to plant collection sites.

In the preparation of the extracts and use of C. uniflora, multiple approaches were commonly encountered, including use of more than one part

TABLE I

Economic status and Educational level of $C$. uniflora users.

\begin{tabular}{lcc}
\hline Economic status & Number & $\mathbf{\%}$ \\
\hline No personal income & 15 & 5.8 \\
Less than 1minimum wage & 14 & 5.3 \\
Between 1and 2 minimum wages & 171 & 65.8 \\
Between 3 and 5 minimum wages & 56 & 21.5 \\
Above 5 minimum wages & 4 & 1.6 \\
\hline Educational level & Number & $\mathbf{\%}$ \\
\hline Illiterate & 12 & 4.5 \\
Primary and middle & 189 & 72.8 \\
Secondary qualification & 48 & 18.5 \\
Undergraduate & 6 & 2.3 \\
Graduate & 5 & 1.9 \\
\hline
\end{tabular}


of the plant, more than one mode of preparation and more than one route of administration (Table II). A majority of users employed the plant's inflorescences, which are macerated in alcohol or rum by $93 \%$ of users. It was also observed that $75 \%$ preferred use of the fresh plant, with $19.6 \%$ drying it before use and $5.4 \%$ did not specify.
Upon analyzing the popular indications described by C. uniflora users, 39 different therapeutic uses were identified (Tables III and IV), the most cited being summarized in Figure 2. However, it is important to note that a majority of participants did not mention just one therapeutic use, but a combination of them.

TABLE II

Plant parts used, modes of preparation and routes of administration cited by $C$. uniflora users.

\begin{tabular}{lcc}
\hline Plant part used & Number & $\%$ \\
\hline Inflorescences & 246 & 94,6 \\
Roots & 18 & 6,9 \\
Leaves & 10 & 3,8 \\
Stems & 4 & 1,5 \\
Whole plant & 3 & 1,2 \\
Shoots & 1 & 0,3 \\
\hline Mode of preparation & Número & $\%$ \\
Maceration & 259 & 99,7 \\
Decoction & 9 & 3,5 \\
Infusion & 7 & 2,7 \\
Poultice & 1 & 0,3 \\
Route of administration & Número & $\%$ \\
Topic & 255 & 98,1 \\
Oral & 88 & 33,8 \\
Otologic & 4 & 1,5 \\
Inhalatory & 1 & 0,3 \\
\hline
\end{tabular}

TABLE III

Indications for popular use with topical $C$. uniflora.

Mode of preparation Part plant used $\quad$ Indication* $\quad$ Mode of use

\begin{tabular}{|c|c|c|c|}
\hline \multirow{6}{*}{ Maceration } & \multirow[t]{2}{*}{ Inflorescences } & $\begin{array}{l}\text { Allergy, anti-inflammatory, antiseptic, } \\
\text { hematoma, wound healing, circulation, } \\
\text { itching, muscle pain, back pain, joint pain, } \\
\text { swelling, urinary tract infection, vaginal } \\
\text { infection, mycosis, snake bites, insect } \\
\text { bites, rheumatism, torsions and varices. }\end{array}$ & $\begin{array}{l}\text { Apply to the affected area } 1-5 \text { times a day } \\
\text { until disappearance of symptoms. }\end{array}$ \\
\hline & & Aphthae and sore throat. & $\begin{array}{l}\text { Gargle, 2-3 times a day until the } \\
\text { disappearance of symptoms }\end{array}$ \\
\hline & Flowers or leaves & Toothache. & $\begin{array}{l}\text { Use cotton soaked with the extract or } \\
\text { use a gargle, rinse or apply a macerated } \\
\text { flower when in pain. }\end{array}$ \\
\hline & $\begin{array}{l}\text { Flowers or leaves } \\
\text { and roots }\end{array}$ & Headache. & $\begin{array}{l}\text { Pass the extract on the forehead, } 2 \\
\text { times a day until the disappearance of } \\
\text { symptoms }\end{array}$ \\
\hline & Leaves & Wound healing, muscle pain and swelling. & $\begin{array}{c}\text { Apply to the affected area } 2-3 \text { times a day } \\
\text { or when in pain until the disappearance } \\
\text { of symptoms. }\end{array}$ \\
\hline & Flowers or roots & $\begin{array}{l}\text { Wound healing, muscle pain and } \\
\text { rheumatism. }\end{array}$ & $\begin{array}{l}\text { Apply to the affected area } 2 \text { times a day } \\
\text { until disappearance of symptoms. }\end{array}$ \\
\hline
\end{tabular}


TABLE III (continuation)

\begin{tabular}{|c|c|c|c|}
\hline Mode of preparation & Part plant used & Indication* & Mode of use \\
\hline \multirow{3}{*}{ Maceration } & Stems & Wound healing. & $\begin{array}{l}\text { Apply to the affected area once daily / } 3 \\
\text { times a week for } 1 \text { month. }\end{array}$ \\
\hline & Shoots & Wound healing and torsions. & $\begin{array}{l}\text { Apply to the affected area } 2 \text { times a day } \\
\text { until disappearance of symptoms. }\end{array}$ \\
\hline & Whole plant & $\begin{array}{l}\text { Wound healing, hematoma and muscle } \\
\text { pain. }\end{array}$ & $\begin{array}{l}\text { Apply to the affected area } 2 \text { times a day } \\
\text { until disappearance of symptoms. }\end{array}$ \\
\hline Poultice & $\begin{array}{l}\text { Inflorescences and } \\
\text { leaves }\end{array}$ & Wound healing. & $\begin{array}{l}\text { Apply to the affected area once daily } \\
\text { until cicatrization. }\end{array}$ \\
\hline \multirow[t]{2}{*}{ Infusion } & Flowers and roots & $\begin{array}{l}\text { Muscle pain, urinary tract infection and } \\
\text { thrombosis. }\end{array}$ & $\begin{array}{l}\text { Apply to the affected area } 2 \text { times a day } \\
\text { until disappearance of symptoms. }\end{array}$ \\
\hline & Roots & Sore throat. & Gargling, once daily until relief of pain. \\
\hline Decoction & Roots & Pain in the broken foot. & $\begin{array}{c}\text { Apply a compress once a day for } 6 \\
\text { months }\end{array}$ \\
\hline
\end{tabular}

Mode of preparation: Macerations are made with rum or alcohol. Infusions are prepared through aqueous decoction. Poultices are prepared with lard. Note: Information about the plant parts used, methods of preparation, therapeutic indications and methods of use present in this Table are described as reported by the study participants.

TABLE IV

Indications for popular use orally, otologically and via inhalation of $C$. uniflora.

Administration Mode of extraction Part of plant Indication Posology-mode of use

Colic, headache, toothache, sore throat, muscle pain, bladder pain, flu, Drink 1-2 teaspoons of extract throat infection, urinary tract infection, diluted in coffee or water, 1-2

Maceration kidney stones, lung problems, reflux, times a day until disappearance of cold, cough and stomach ulcer with symptoms. Helicobacter pylori.

\begin{tabular}{|c|c|c|c|}
\hline & \multirow{4}{*}{ Inflorescences } & \\
\hline Maceration & & $\begin{array}{l}\text { Expectorant and in the treatment of } \\
\text { sinusitis. }\end{array}$ & $\begin{array}{l}\text { Mix } 30 \% \text { water }+30 \% \text { extract } \\
+40 \% \text { lemon juice, drink } 1 \\
\text { glass 3-4 times a day until } \\
\text { disappearance of symptoms. }\end{array}$ \\
\hline Infusion & & $\begin{array}{l}\text { Anti-inflammatory, colic, stomach } \\
\text { pain, flu, infection. }\end{array}$ & $\begin{array}{l}\text { Drink 1-3 cups of infusion at night } \\
\text { until disappearance of symptoms. }\end{array}$ \\
\hline Decoction & & $\begin{array}{l}\text { Anti-inflammatory, wound healing, } \\
\text { swelling, rheumatism and after } \\
\text { surgical removal of the ovaries. }\end{array}$ & $\begin{array}{l}\text { Drink half to } 1 \text { cup, } 1-3 \text { times a } \\
\text { day for } 7 \text { days. }\end{array}$ \\
\hline Maceration & \multirow{2}{*}{$\begin{array}{l}\text { Flowers and } \\
\text { roots }\end{array}$} & Colic and bladder pain. & $\begin{array}{l}\text { Drink } 10-15 \text { drops diluted } \\
\text { in coffee, } 2 \text { times a day until } \\
\text { disappearance of symptoms. }\end{array}$ \\
\hline Infusion & & Colic and headache. & $\begin{array}{l}\text { Drink } 1 \text { cup, } 2 \text { times a day until } \\
\text { disappearance of symptoms. }\end{array}$ \\
\hline Maceration & \multirow{2}{*}{ Roots } & Urinary infection. & $\begin{array}{c}\text { Drink } 2 \text { tablespoons diluted in tea/ } \\
\text { coffee or water, } 2 \text { times a day until } \\
\text { disappearance of symptoms. }\end{array}$ \\
\hline Decoction & & Diabetes. & $\begin{array}{l}\text { Drink } 1 \text { liter per day in small } \\
\text { doses, every day. }\end{array}$ \\
\hline Maceration & \multirow{2}{*}{$\begin{array}{l}\text { Roots and } \\
\text { leaves }\end{array}$} & Flu, infection and cold. & $\begin{array}{c}\text { Drink } 1 \text { teaspoon of extract } \\
\text { diluted in coffee or water, once } \\
\text { a day. }\end{array}$ \\
\hline Decoction & & Urinary infection. & $\begin{array}{l}\text { Drink } 1 \text { cup, } 3 \text { times a day, for } 7 \\
\text { days. }\end{array}$ \\
\hline Infusion & Leaves & $\begin{array}{l}\text { Wound healing, infection and } \\
\text { rheumatism }\end{array}$ & $\begin{array}{l}\text { Drink } 1 \text { teaspoon, } 3 \text { times a day, } \\
\text { for } 15 \text { days. }\end{array}$ \\
\hline
\end{tabular}


TABLE IV (continuation)

\begin{tabular}{lcccc}
\hline Administration & Mode of extraction & Part of plant & Indication & Posology-mode of use \\
\hline Otological use & Maceration & Inflorescences & Earache. & $\begin{array}{c}\text { Use cotton wetted with extract or } \\
\text { instill 3-4 drops, 1-3 times a day }\end{array}$ \\
\hline Inhalational use & Decoction & Flowers & $\begin{array}{c}\text { Simmer the flowers with water } \\
\text { and salt and inhale steam, once } \\
\text { daily until disappearance of } \\
\text { symptoms. }\end{array}$ \\
\hline
\end{tabular}

Mode of preparation: Macerations are made with rum or alcohol. Infusions are prepared through aqueous decoction. Note: Information about the parts of the plant used, methods of preparation, therapeutic indications and methods of use present in this Table are described as reported by the study participants.

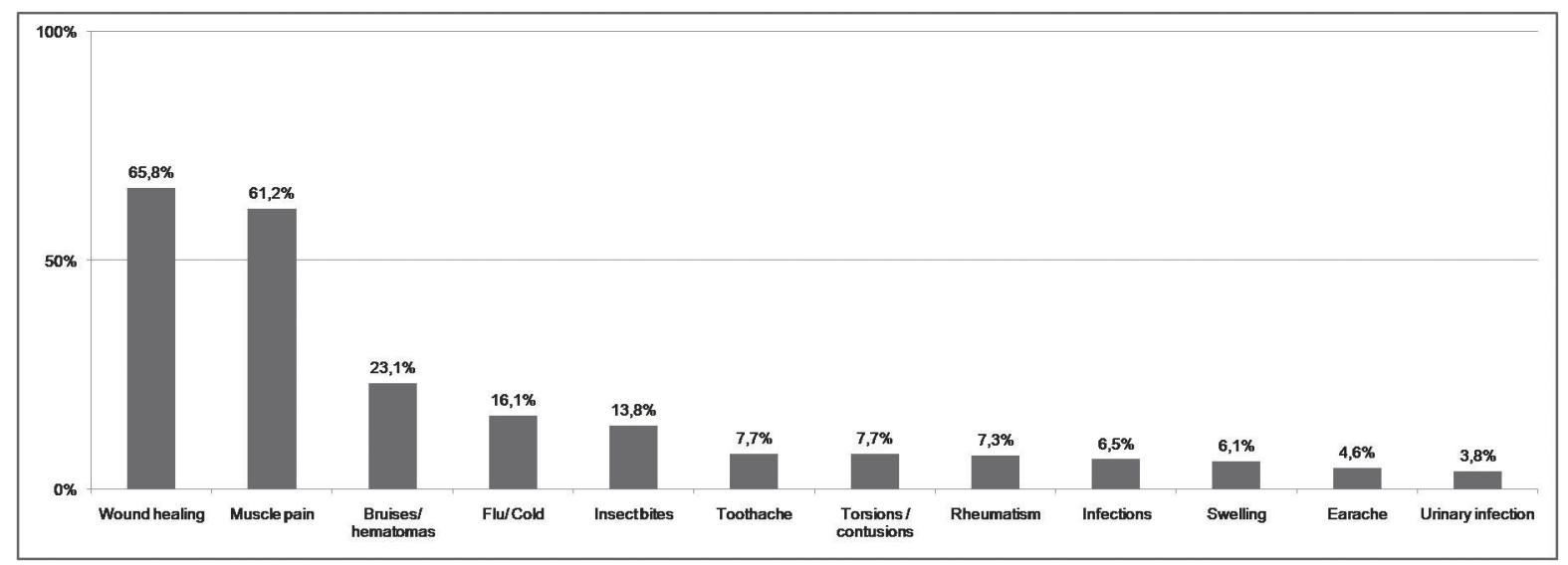

Figure 2 - Main therapeutic indications cited by C. uniflora users.

In relation to the recommendation of use of C. uniflora by health professionals, only $6.2 \%$ of users reported using the plant on the advice of these sources. Concerning the perceptions of effectiveness with $C$. uniflora, $97 \%$ of informants who used the plant said they experienced improvement with its use. When questioned about the safety of the plant, $98.5 \%$ of respondents said that it has no toxicity and approximately $85 \%$ that it has no contraindications or drug interactions.

\section{DISCUSSION}

The demographic characteristics of the participants in this study have many parallels with published work. Age profiles of respondents in this study match closely with those in the literature; in the work of Gbolade (2012), 43\% of respondents were between 30 and 50 years, and $49 \%$ were over 50 years (compared to $37 \%$ and $47 \%$ respectively).
Liu et al. (2014) observed an age range of respondents of 16 to about 70 years, which again represents a similar age profile to that seen in the present work. The average age of $C$. uniflora users was also similar to that found in the work of Muthee et al. (2011) and Bulut and Tuzlaci (2013) with other plants, where the average ages were 55 and 53, respectively. It is important to highlight the influence of older people in the dissemination of knowledge through the generations, as such people are a source of potential information on the use of medicinal plants (Rokaya et al. 2010, Silva et al. 2010, Dovie et al. 2008). According to some authors, younger people know less about medicinal plants than older people (Juárez-Vázquez et al. 2013). Gakuya et al. (2013) reported an average age of participants of 60 years, suggesting that the new generation is not fully engaged in the practice of traditional medicine, due to a decline in the dissemination of knowledge across generations. 
Interestingly however, it was found in this study that approximately $30 \%$ of who use C. uniflora were less than 40 years, showing the use of this species by newer generations also.

Ethnobotanical studies describing self-selection of medicinal plants often show that the female sex predominates with such use, as observed herein where $74 \%$ participants were female. This may be related to the fact that men are working outside the home and women more involved with domestic responsibilities (Al-Adhroey et al. 2010, Jesus et al. 2009, Liu et al. 2014, Sivasankari et al. 2014) claim that women have a greater interest in the use of medicinal plants. Moreover, it is common for them to have accumulated more information on plant use than men, reflecting their traditional roles in the care of home and children, in order to preserve family and community health (Abe and Ohtani 2013). In the present study, $34.1 \%$ of participants identified as female homemakers and $22.3 \%$ were retired, including some women. In contrast, in ethnobotanical studies of plant use by traditional healers, in some cultures it may be more common for the repository of knowledge to lie predominantly with men (Ngarivhume et al. 2015).

One of the factors commonly cited to explain the ongoing widespread use of medicinal plants in the world is the affordable cost of such therapy, which is usually associated with developing countries and low income (Yabesh et al. 2014, Maroyi 2011). Individuals with lower educational levels may also have more contact with the use of medicinal plants when compared to people with a higher education level (Kayani et al. 2014). In the present study, almost $80 \%$ of participants did not proceed to secondary education. These percentages were very similar to those observed by Gakuya et al. (2013) and Kaval et al. (2014) in analogous studies with other plant species. The economic situation of the majority of respondents (Table I) was similar to that found by Santos et al. (2009); however the economic status does not directly predict use of $C$. uniflora as clearly, as $21.5 \%$ reported their monthly income as between 3 and 5 wages.

As with other studies (Juárez-Vázquez et al. 2013, Jesus et al. 2009), a majority of participants collected $C$. uniflora directly from its natural habitat. Mondin (2015) describes that $C$. uniflora is appearing on the southern coast of Santa Catarina in sandy well-drained soils. Flowering usually occurs from September to March and May to July, predominantly in October and November, matching the most common time of harvesting reported by users. Such information is very valuable, as the production of chemical substances can vary depending on stages of growth and collection period, in addition to other environmental factors, exposure to pesticides and heavy metal contamination (Padma 2005). Furthermore, the availability of nutrients, carbon dioxide, ozone, light and appropriate temperature, also can change the production of secondary metabolites (McKiernan et al. 2014).

A lack of standardization in the preparation and use of plant extracts seems to be one of the main drawbacks of traditional medicine, as there is often no well-defined ratio between the quantity of plant material and solvent to be used (Al-Adhroey et al. 2010). In the present study this was also observed, since many different forms of preparation of $C$. uniflora extracts were documented (Tables III and IV). Regarding maceration, many said that the plant should stay in contact with the liquid (alcohol or rum) for a few days or until the liquid is yellowish. After this period, the extract can then be used, and may be subsequently stored until it runs out. In contrast, if employing a decoction or infusion, users leave the plant in contact with the solvent (water) only for a few minutes, with such extracts being completely consumed after preparation. Clearly, use of different solvents and preparation methods may likely afford extracts with varying phytochemical fingerprints.

Studies performed with both aerial and underground parts of $C$. uniflora have revealed 
interesting biological activities (Nascimento et al. 2002, 2004, 2007). These investigations, coupled with the observations of this study regarding methods of use of C. uniflora, may suggest a higher concentration of active compounds in inflorescences and roots. However, more studies are needed to afford a complete chemical profile of the species.

Constituents responsible for the therapeutic action of plants are typically secondary compounds such as alkaloids, phenolic compounds, essential oils and others (Halberstein 2005, Gurib-Fakim 2006, Wink 2013). These metabolites, in most cases, exhibit some biological activity. Polyphenols, for example, are generally pharmacologically active, with diverse actions including antioxidant, antiinflammatory, antibacterial, antifungal and antiviral activities (Wink 2013).

In the present study, none of the biological activities described by the literature were specifically described by $C$. uniflora users, although the reference to use in vaginal infection may correlate with observed anti-fungal effects. But this affirmation is merely speculative. Interestingly however, in our laboratory, a study showed that alcoholic extracts of the inflorescences of $C$. uniflora have antinociceptive activity in mice (unpublished data), which may pharmacologically validate the use of this plant as an anti-inflammatory and analgesic. In light of these observations, further studies are needed to clarify whether the therapeutic actions mentioned by the user population of $C$. uniflora in souther Brazil are due to reported or as yet uncharacterized constituents.

Other published ethnobotanic studies show that other plants of the family Asteraceae are used for the same therapeutic purposes as C. uniflora in southern Brazil (Rokaya et al. 2010, Abe and Ohtani 2013, Gakuya et al. 2013, Juárez-Vázquez et al. 2013, Bulut and Tuzlaci 2013, Leto et al. 2013, Kayani et al. 2014). It remains to be ascertained whether the active constituents of these species overlap with those of $C$. uniflora or are distinct. Besides, southern region of Brazil is colonized by European immigrants who were decisive in the cultural habits of the region. So it is important to note that Arnica-da-praia may have been confused by Spanish immigrants with Arnica montana L., since they are very similar morphologically in size and inflorescence, because both are small herbs and have chapters with yellow flowers. This idea is supported by the therapeutic indications of $A$. montana, which is known worldwide and used for the same medicinal purposes described in this survey for $C$. uniflora as analgesic, for contusion, bowels ache, common cold, cough, hematoma, headache, phlebitis, rheumatism and others applications (for review, see Obón et al. 2012).

In this study, only a minority of participants reported the use of $C$. uniflora pursuant to recommendation from a healthcare professional. A lack of access to modern health services is often cited as a factor that leads people to choose medicinal plants as a primary resource for the treatment of their health problems, which may partly account for this finding (Kayani et al. 2014, Simbo 2010). Another factor that may explain the low rate of use of the plant as directed by healthcare professionals is the fact that many have acquired knowledge of the species through their family. However, as emphasized by Rossato and Chaves (2012), only those medicinal plants that have been validated with the National Agency of Sanitary Vigilance (ANVISA) should be indicated by health professionals in Brazil. No information was found on C. uniflora in RDC No. 26 of May 13, 2014, or in Instruction No. 2 of May 13, 2014, or in the monographs on herbal traditional use of the European Community (Community herbal monographs with traditional use). Notably however, the vast majority of $C$. uniflora users expressed confidence in its efficacy without fear of significant side effects. Such beliefs undoubtedly motivate ongoing confidence in the medicinal use 
of this species. It is estimated that $70-80 \%$ of people worldwide rely mainly on traditional medicines, usually herbal medicines, to meet their basic health needs (Hamilton 2004). Many people prefer the use of medicinal plants to allopathic drugs as they consider that they have fewer side effects than synthetic drugs (Gakuya et al. 2013, Kayani et al. 2014). However, the secondary metabolites of plants do not always provide benefits, and may cause toxicity depending on the concentration present or through inappropriate use (Turolla and Nascimento 2006). Furthermore, they can trigger adverse reactions by interacting with other drugs or food, or due to patient characteristics such as age, gender, physiological conditions, genetic traits, etc (Balbino and Dias 2010). Thus, care in the therapeutic use of plants is essential due to a lack of knowledge about the interactions between plant extracts and synthetic drugs (Rossato and Chaves, 2012, Juárez-Vázquez et al. 2013); this is particularly of concern for little-studied species such as C. uniflora.

\section{CONCLUSIONS}

In this study, it was found that C. uniflora is widely known and used in Brazil, considering that of the $94.1 \%$ of respondents who recognized it, $74.3 \%$ utilize it as a medicinal plant.

In relation to popular indications, it was noted that the plant is most commonly used for wound healing, muscle pain, bumps and hematomas, flu and cold, insect bites and toothache. Furthermore, it was found that people have great confidence in the use of this plant, $98.5 \%$ considering it to be nontoxic and $85 \%$ asserting that it has no contraindications and drug interactions.

In conclusion, in light of its widespread recognition and utilization as a medicinal plant for a range of diverse indications, future phytochemical, pharmacological and toxicological analyzes informed by the results of this study are warranted, in order to ensure safe use of the species and validate its popular use.

\section{ACKNOWLEDGMENTS}

We are thankful Dra ${ }^{\mathrm{a}}$. Mara Rejane Ritter for botanical identification of C. uniflora.

\section{REFERENCES}

ABBET C, SLACANIN I, CORRADI E, DE MIERI M, HAMBURGER M AND POTTERAT O. 2014. Comprehensive analysis of Cirsiumspinosis simum Scop., a wild alpine food plant. Food Chem 160: 165-170.

ABE R AND OHTANI K. 2013. An ethnobotanical study of medicinal plants and traditional therapies on Batan Island, the Philippines. J Ethnopharmacol 145: 554-565.

AL-ADHROEY AH, NOR ZM, AL-MEKHLAFI HM AND MAHMUD R. 2010. Ethnobotanical study on some Malaysian anti-malarial plants: A community based survey. J Ethnopharmacol 132: 362-364.

ALBUQUERQUE UP, LUCENA RP AND ALENCAR NL. 2010. Métodos e técnicas para coleta de dados etnobiológicos. In: Albuquerque UP, Lucena RFP and Cunha LVFC (Eds), Métodos e técnicas na pesquisa etnobiológica e etcoecológica. E-Publishing Inc., Recife, p. 41-64.

ALLABI AC, BUSIA K, EKANMIAN V AND BAKIONO F. 2010. The use of medicinal plants in self-care in the Agonlin region of Benin. J Ethnopharmacol 133: 234-243.

BALBINO EE AND DIAS MF. 2010. Farmacovigilância: um passo em direção ao uso racional de plantas medicinais e fitoterápicos. Rev Bras Farmacogn 20: 992-1000.

BALNEÁRIO RINCÃO. 2014. Bem-vindo ao Balneário Rincão. http://www.balneariorincao.sc.gov.br/cms/pagina/ ver/codMapaItem/4776\#.U6HtBSjgI5g. Accessed 14 October 2014.

BRASIL. 2012. Resolução n ${ }^{\circ} 466$ de 12 de dezembro de 2012. Estabelece as diretrizes e normas regulamentadoras de pesquisas envolvendo seres humanos. Conselho Nacional de Saúde. http://bvsms.saude.gov.br/bvs/saudelegis/ cns/2013/res0466_12_12_2012.html Accessed 25 March, 2013.

BULUT G AND TUZLACI E. 2013. An ethnobotanical study of medicinal plants in Turgutlu (Manisa - Turkey). J Ethnopharmacol 149: 633-647.

DOVIE DBK, WITKOWSKI ETF AND SHACKLETON CM. 2008. Knowledge of plant resource use based on location, gender and generation. Appl Geor 28: 311-322.

GAKUYA DW, ITONGA SM, MBARIA JM, MUTHEE JK AND MUSAU JK. 2013. Ethnobotanical survey of biopesticides and other medicinal plants traditionally used 
in Meru central district of Kenya. J Ethnopharmacol 145: 547-553.

GBOLADE A. 2012. Ethnobotanical study of plants used in treating hypertension in Edo State of Nigeria. J Ethnopharmacol 144: 1-10.

GURIB-FAKIM A. 2006. Medicinal plants: Traditions of yesterday and drugs of tomorrow. Mol Asp Med 27: 1-93.

HALBERSTEIN RA. 2005. Medicinal Plants: Historical and Cross-Cultural Usage Patterns. Ann Epidemiol 15: 686699.

HAMILTON AC. 2004. Medicinal plants, conservation and livelihoods. Biodivers Conserv 13: 1477-1517.

HEINRICH M, HALLER BF AND LEONTI M. 2014. A Perspective on Natural Products Research and Ethnopharmacology in Mexico: The Eagle and the Serpent on the Prickly Pear Cactus. J Nat Prod 77: 678-689.

IBGE. 2012. Diretoria de Pesquisas - DPE. Coordenação de População e Indicadores Sociais - COPIS. Balneário Rincão. Estimativa da População. http://www.ibge.gov. br/cidadesat/link.php?codmun=422000. Accessed March 25, 2013.

JESUS NZT, LIMA JCS, SILVA RM, ESPINOSA MM AND MARTINS DTO. 2009. Levantamento etnobotânico de plantas popularmente utilizadas como antiúlceras e antiinflamatórias pela comunidade de Pirizal, Nossa Senhora do Livramento-MT, Brasil. Rev Bras Farmacogn 19: 130139.

JUÁREZ-VÁZQUEZ MDC, CARRANZA-ÁLVAREZ C, ALONSO-CASTRO AJ, GONZÁLEZ-ALCARAZ VF, BRAVO-ACEVEDO E AND CHAMARRO-TINAJERO FJ. 2013. Ethnobotany of medicinal plants used in Xalpatlahuac, Guerrero, México. J Ethnopharmacol 148: 521-527.

KAVAL I, BEHÇET L AND CAKILCIOGLU U. 2014. Ethnobotanical study on medicinal plants in Geçitli and its surrounding (Hakkari-Turkey). J Ethnopharmacol 155: 171-184.

KAYANI S, AHMAD M, ZAFAR M, SULTANA S, KHAN MPZ AND ASHRAF MA. 2014. Ethnobotanical uses of medicinal plants for respiratory disorders among the inhabitants of Gallies - Abbottabad, Northern Pakistan. J Ethnopharmacol 156: 47-60.

LETO C, TUTTOLOMONDO T, LA BELLA S AND LICATA M. 2013. Ethnobotanical study in the Madonie Regional Park (Central Sicily, Italy) - Medicinal use of wild shrub and herbaceous plant species. J Ethnopharmacol 146: 90112.

LIU Y, AHMED S, LIU B, GUO Z, HUANG W, WU X, LI S, ZHOU J, LEI Q AND LONG C. 2014 Ethnobotany of dye plants in Dong communities of China. J Ethnobiol Ethnomed 19: 10-23.

LIMA TC, SOUZA RJ, SANTOS AD, MORAES MH, BIONDO NE, BARISON A, STEINDEL M AND BIAVATTI MW. 2016. Evaluation of leishmanicidal and trypanocidal activities of phenolic compounds from Calea uniflora Less. Nat Prod Res 30(5): 551-557.

MAIA GLA, FALCÃO-SILVA VS, AQUINO PGV, ARAÚJOJÚNIOR JX, TAVARES JF AND SILVA MS. 2011. Flavonoids from Praxel clematidea R.M. King and Robinson Modulate Bacterial Drug Resistance. Molecules 16: 4828-4835.

MAROYI A. 2011. An ethnobotanical survey of medicinal plants used by the people in Nhemacommunal area, Zimbabwe. J Ethnopharmacol 136: 347-354.

MCKIERNAN AB, HOVENDEN MJ, BRODRIBBA TJ, POTTS BM, DAVIES NW AND O'REILLY-WAPSTRA JM. 2014. Effect of limited water availability on foliar plant secondary metabolites of two Eucalyptus species. Environ Exp Bot 105: 55-64.

MONDIN CA, ROQUE N AND BRINGEL JR JBA. 2015. Calea in Lista de Espécies da Flora do Brasil. Jardim Botânico do Rio de Janeiro. 2015. http://floradobrasil.jbrj. gov.br/jabot/floradobrasil/FB103757. Accessed 13 July 2015.

MUTHEE JK, GAKUYA DW, MBARIAB JM, KARERU PG, MULEI CM AND NJONGE FK. 2011. Ethnobotanical study of anthelmintic and other medicinal plants traditionally used in Loitoktok district of Kenya. J Ethnopharmacol 135: 15-21.

NASCIMENTO AM, COSTA FC, THIEMANN OH AND OLIVEIRADCR. 2007. Chromanones with Leishmanicidal Activity from Calea uniflora. Z Naturforsch C Biosci 62: 353-356.

NASCIMENTO AM AND OLIVEIRA DCR. 2004. A 5-deoxyflavone glycoside from Calea uniflora L. (Asteraceae). Biochem Syst Ecol 32: 1079-1081.

NASCIMENTO AM AND OLIVEIRA DCR. ALBUQUERQUE S. 2002. Evaluation of trypanocidal activity from Calea uniflora (Heliantheae - Asteraceae) extracts. Rev Bras Farmacogn 12: 49-50.

NASCIMENTO AM, SALVADOR MJ, CANDIDO RC, ALBUQUERQUE S AND OLIVEIRA DCR. 2004. Trypanocidal and antifungal activities of p-hydroxyacetophenone derivatives from Calea uniflora (Heliantheae, Asteraceae). J Pharm Pharmacol 56: 663-669.

NGARIVHUME T, VAN'TKLOOSTER CI, DE JONG JT AND VAN DER WESTHUIZEN JH. 2015. Medicinal plants used by traditional healers for the treatment of malaria in the Chipinge district in Zimbabwe. J Ethnopharmacol 159: 224-237.

OBÓN C, RIVERA D, VERDE A, FAJARDO J, VALDÉS A, ALCARAZ F. 2012. Árnica: a multivariate analysis of the botany and ethnopharmacology of a medicinal plant complex in the Iberian Peninsula and the Balearic Islands. J Ethnopharmacol 144: 44-56.

PADMA TV. 2005. Ayurveda: Science and business are racing to tap the 3,000-year old system of medicine for new drugs. Nature: 436. 
ROKAYA MB, MUNZBERGOVA Z AND TIMSINA B. 2010. Ethnobotanical study of medicinal plants from the Humla district of western Nepal. J Ethnopharmacol 130: 485-504.

ROSSATO AE AND CHAVES TRC. 2012. Fitoterapia Racional: aspectos taxonômicos, agroecológicos, etnobotânicos e terapêuticos. In: Rossato AE, Pierini MM, Amaral PA, Santos RR and Citadini-Zanette V (Eds), Fitoterapia Racional: aspectos taxonômicos, agroecológicos, etnobotânicos e terapêuticos. E-Publishing Inc., Florianópolis, p. 16-39.

ROSSATO AE, PIERINI MM, AMARAL PA, SANTOS RR AND CITADINI-ZANETTE V. 2012. Instrumentos de pesquisa: utilizados em trabalhos de conclusão de curso e levantamentos etnobotânicos realizados pelo Grupo de Extensão e Pesquisa em Plantas Medicinais (GEPPLAM/UNESC). In: ROSSATO AE, PIERINI MM, AMARAL PA, SANTOS RR and CITADINI-ZANETTE V (Eds), Fitoterapia Racional: aspectos taxonômicos, agroecológicos, etnobotânicos e terapêuticos. E-Publishing Inc., Florianópolis, 192-213.

SANTA CATARINA. 2014. Geografia. http://www.sc.gov.br/ index.php/geografia. Accessed 18 October 2014.

SANTOS EB, DANTAS GS, SANTOS HB, DINIZ MFFM AND SAMPAIO FC. 2009. Estudo etnobotânico de plantas medicinais para problemas bucais no município de João Pessoa, Brasil. Rev Bras Farmacogn 19: 321-324.

SARGIN SA, AKÇICEK E AND SELVI S. 2013.An ethnobotanical study of medicinal plants used by the local people of Alaşehir (Manisa) in Turkey. J Ethnopharmacol 150: 860-874.

SASLIS-LAGOUDAKIS CH, HAWKINS JA, GREENHILL SJ, PENDRY CA, WATSON MF, TULADHAR-
DOUGLAS W, BARAL SR AND SAVOLAINEN V. 2014. The evolution of traditional knowledge: environment shapes. Proc R Soc B Biol Sci 281: 1-7.

SILVA MAB, MELO LVL, RIBEIRO RV, SOUZA JPM, LIMA JCS AND MARTINS DTO. 2010. Levantamento etnobotânico de plantas utilizadas como antihiperlipidêmicas e anorexígenas pela população de Nova Xavantina-MT, Brasil. Rev Bras Farmacogn 20: 549-562.

SIMBO DJ. 2010. An ethnobotanical survey of medicinal plants in Babungo, Northwest Region, Cameroon. J Ethnobiol Ethnomed 6: 1-7.

SIVASANKARI B, ANANDHARAJ M AND GUNASEKARAN P. 2014. An ethnobotanical study of indigenous knowledge on medicinal plants used by the village peoples of Thoppampatti, Dindigul district, Tamilnadu, India. J Ethnopharmacol 153: 408-423.

TUROLLAMSRAND NASCIMENTO ES. 2006. Informações toxicológicas de alguns fitoterápicos utilizados no Brasil. Braz J Pharm Sci 42: 289-306

WAMBUGU SN, MATHIU PM, GAKUYA DW, KANUI TI, KABASA JD AND KIAMA SG. 2011. Medicinal plants used in the management of chronic joint pains in Machakos and Makueni counties, Kenya. J Ethnopharmacol 13: 945 955.

Wink M. 2013. Evolution of secondary metabolites in legumes (Fabaceae). S. Afr. J. Bot. 89, 164-175.

YABESH JEM, PRABHU S AND VIJAYAKUMAR S. 2014. An ethnobotanical study of medicinal plants used by traditional healers in silent valley of Kerala, India. J Ethnopharmacol 154: 774-789. 